*

THE CRISIS OF

* THE OLD ORDER *

IN RUSSIA

* 
Studies of the Russian Institute

Columbia University

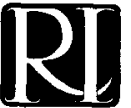


㭃

\title{
Roberta
}

Thompson

Manning

\section{THE CRISIS OF}

* THE OLD ORDER *

IN RUSSIA

Gentry and

Government

\author{
荻 \\ PRINCETON \\ UNIVERSITY \\ PRESS
}




\section{Copyright $(\mathcal{C} 1982$ by Princeton University Press}

\section{Published by Princeton University Press, 41 William St., Princeton, New Jersey}

In the United Kingdom: Princeton University Press, Guildford, Surrey

\section{All Rights Reserved}

Library of Congress Cataloging in Publication Data will be found on the last printed page of this book

The Russian Institute of Columbia University sponsors the Studies of the Russian Institute in the belief that their publication contributes to scholarly research and public understanding. In this way the Institute, while not necessarily endorsing their conclusions, is pleased to make available the results of some of the research conducted under its auspices. A list of the Studies of the Russian Institute appears at the back of this book.

This book has been composed in Linotron Times Roman

Clothbound editions of Princeton University Press books are printed on acid-free paper, and binding materials are chosen for strength and durability

Printed in the United States of America by Princeton University Press, Princeton, New Jersey

Princeton Legacy Library edition 2019

Paperback ISBN: 978-0-691-65564-2

Hardcover ISBN: 978-0-691-65706-6 
To

Jerry

and

Innessa 
